\title{
Penggunaaan alat peraga petak-petak urutan bilangan pecahan bagi peningkatan kompetensi siswa dalam menentukan urutan tertentu dari sekelompok bilangan pecahan acak
}

\author{
Endang Sumarwanti \\ SDN 01 Batursari Kecamatan Talun Kabupaten Pekalongan
}

\begin{tabular}{ll}
\hline Article Info & ABSTRACT \\
\hline Article history: & $\begin{array}{l}\text { The purpose of this study is to describe the impact of using props in number } \\
\text { sequence plots. This research was conducted on Mathematics subject about } \\
\text { Received : 28 Juli } 2021\end{array}$ \\
$\begin{array}{l}\text { Revised : 7 September 2021 numbers in grade VI SD Negeri 01 Batursari, Talun District, } \\
\text { Accepted : 24 September 2021 }\end{array}$ & $\begin{array}{l}\text { Pekalongan Regency in two cycles. The use of teaching aids in the form of } \\
\text { plots of number sequences that are explained systematically in learning by }\end{array}$ \\
\hline teachers can actually improve students' abilities and skills in sorting groups \\
of numbers arranged in a certain order (from sequential to largest). The \\
increase in the number of students who achieved learning completeness was \\
props; fractional numbers; plots \\
at least 11 students (64.70\%) to 14 students (82.35\%). The class average also \\
increased from 73.52 to 86.47. The use of appropriate media and teaching \\
aids in learning must be planned and carried out by the teacher so that the \\
message conveyed can be received by students as a whole and realistically, \\
especially in learning mathematics.
\end{tabular}

(*) Corresponding Author:

endang.sumarwanti@gmail.com

How to Cite: Sumarwanti, E. (2021). Penggunaaan alat peraga petak-petak urutan bilangan pecahan bagi peningkatan kompetensi siswa dalam menentukan urutan tertentu dari sekelompok bilangan pecahan acak. Action Research Journal, 1(1): 30-39.

\section{PENDAHULUAN}

Pendidikan adalah proses membantu siswa agar berkembang secara optimal. Pendidikan bukan proses memaksakan kehendak orang dewasa (guru) kepada siswa, melainkan upaya menciptakan kondisi yang kondusif bagi perkembangan anak, yaitu kondisi yang memberi kemudahan kepada anak untuk mengembangkan dirinya secara optimal. Artinya di dalam proses pendidikan siswa aktif mengembangkan diri dan guru aktif membantu menciptakan kemudahan (facilitating) untuk perkembangan yang optimal itu. (Hera Lestari Mikarsa, 2007). Mencapai tujuan pendidikan tidaklah semudah membalikkan telapak tangan. Dibutuhkan kiat-kiat khusus di bidang pendidikan dari kebijakan pejabat yang berwenang, tenaga-tenaga ahli dan profesional, serta sarana dan prasarana pendidikan yang memadai. Guru sebagai tenaga profesioanal dan ujung tombak dalam pencapaian tujuan pendidikan dituntut untuk selalu mencari gagasan-gagasan baru (inovasi), berusaha menyempurnakan pelaksanaan tugas mengajar, mencobakan berbagai metode dan strategi, serta selalu berupaya membuat dan menggunakan alat peraga dalam pembelajarannya.

Pada kesempatan kali ini Peneliti yang berlatar belakang sebagai guru kelas VI di SD Negeri 01 Batursari, Kecamatan Talun, Kabupaten Pekalongan, berupaya memaparkan pelaksanaan tindakan perbaikan pembelajaran melalui Penelitian Tindakan Kelas (PTK) pada mata pelajaran Matematika tentang mengurutkan sekelompok bilangan pecahan yang tersusun acak di kelas VI SD Negeri 01 Batursari. Matematika merupakan satu dari tiga mata pelajaran yang diujikan pada Ujian Sekolah Berstandar Nasional (USBN) tahun pelajaran 2017/2018. Peneliti sebagai guru kelas VI, sudah selayaknya lebih berbenah diri dan melakukan upaya- 
upaya dan tindakan preventif seperti perbaikan pembelajaran dalam mengantisipasi pelaksanaan USBN tahun 2018 ini sehingga siswa kelas VI yang berjumlah 17 siswa kelak dapat lulus $100 \%$ dan dengan hasil yang memuaskan. Data dua tahun terakhir menunjukkan bahwa nilai rata-rata hasil Ujian Sekolah untuk mata pelajaran matematika sangat rendah. Pada tahun 2016 nilai rata-rata Ujian Sekolah untuk mata pelajaran Matematika 54,8 dan pada tahun 2017 justru menurun menjadi 50,5. Sementara pada hasil evaluasi Ujian Akhir Semester 1 tahun 2017/2018 pun nilai rata-ratanya cukup rendah yaitu 56 dan dari 17 siswa yang memperoleh nilai lebih dari 75 hanya 1 orang. Padahal menurut teori belajar tuntas (mastery learning) pembelajaran dikatakan berhasil dan dapat dilanjutkan pada materi berikutnya jika siswa yang dapat menguasai materi $75 \%$ adalah $75 \%$ dari jumlah siswa. Berarti jika siswa kelas VI SDN 01 Batursari sebanyak 17 siswa, maka minimal 13 siswa harus sudah dapat menguasai materi atau tujuan pembelajaran mencapai $75 \%$. Hal ini baru dapat dikatakan bahwa pembelajaran berhasil dan dapat dilanjutkan ke materi berikutnya.

Peneliti melakukan perbaikan pembelajaran ini karena pada pembelajaran awal, kemampuan dan keterampilan siswa dalam mengurutkan sekelompok pecahan yang acak sangat rendah yang dibuktikan pada evaluasi formatif hanya diperoleh nilai rata-rata kelas 52,94 dan hanya ada seorang siswa atau 5,88\% yang mencapai ketuntasan belajar. Padahal, Peneliti menetapkan $\geq 75 \%$ sebagai batas minimal ketuntasan belajar. Kenyataan tersebut menandai adanya permasalahan dalam pembelajaran yang dilakukan oleh peneliti. Berdasarkan uraian di atas, maka identifikasi masalah: siswa mengalami kesulitan dalam menyamakan penyebut dari sekelompok bilangan pecahan berpenyebut tidak sama yang harus diurutkan. Siswa mengalami kesulitan dan kesalahan dalam menempatkan urutan tertentu dari sekelompok bilangan pecahan berpenyebut tidak sama yang diacak urutannya. Siswa banyak mengalami kesulitan pada saat mengubah pecahan persen campuran menjadi pecahan biasa,sehingga terjadi kesalahan dalam mengurutkannya. Ada beberapa siswa yang kurang merespon terhadap penjelasan guru dan diskusi kelompok sehingga mengalami kesulitan dalam menentukan urutan dari sekelompok bilangan pecahan acak urutannya secara individu.

Berdasarkan pada identifikasi dan analisis masalah yang dihadapi Peneliti dalam pembelajaran matematika tentang mengurutkan pecahan berpenyebut tidak sama maka diperoleh rumusan masalah sebagai berikut :

1. Bagaimanakah penggunaan alat peraga berupa petak-petak urutan bilangan pecahan yang dirancang oleh guru dapat meningkatkan kemampuan dan keterampilan siswa dalam menentukan urutan tertentu dari sekelompok bilangan pecahan berpenyebut tidak sama yang tersusun acak?

2. Bagaimana peningkatan bimbingan individu dan penggunaan penguatan (reinforcement) dalam pembelajaran dapat meningkatkan kemampuan dan keterampilan siswa dalam menentukan urutan tertentu dari sekelompok bilangan pecahan berpenyebut tidak sama yang tersusun acak?

\section{METODE}

Peneliti melaksanakan PTK pada mata pelajaran Matematika tentang mengurutkan bilangan pecahan di kelas sendiri, yaitu kelas VI SD Negeri 01 Batursari, Kecamatan Talun, Kabupaten Pekalongan. Siswa kelas VI berjumlah 17 siswa yang terdiri dari 10 siswa laki-laki dan 7 siswa perempuan yang menempati sebuah ruang kelas yang berukuran 7 x 8 x $1 \mathrm{~m} 2$. SD Negeri 01 Batursari terletak di Jalan Raya Batursari Kecamatan Talun Kabupaten Pekalongan dalam upaya meningkatkan mutu pendidikan SD Negeri 01 Batursari untuk mewujudkan visi dan misinya. Peneliti melakukan penelitian tindakan kelas pada mata pelajaran Matematika kelas VI dengan materi pokok mengurutkan bilangan pecahan dalam dua siklus perbaikan pembelajaran pada bulan Februari 2018 yaitu. siklus I pada hari Selasa, 13 Februari 2018, siklus II pada Selasa, 20 Februari 2018.

Adanya perbedaan individu dalam mencapai suatu tujuan dalam pembelajaran, bahwa antara siswa yang satu dengan siswa yang lain belum tentu dapat mencapai tujuan tersebut 
dalam waktu yang bersamaan. Ada siswa yang cepat ada juga siswa yang lamban. Penelitian Tindakan Kelas adalah bentuk kegiatan guru yang tepat mengatasi permasalahan dalam pembelajaran yang dilakukan. Kemmis dan Mc. Taggart memberikan acuan agar tujuan pembelajaran dapat dicapai dengan baik oleh $\geq 75 \%$ siswa peserta pembelajaran, maka sebaiknya dilakukan perbaikan pembelajaran dengan siklus berulang. Teori siklus berulang inilah yang akan digunakan Peneliti dalam melaksanakan perbaikan pembelajaran melalui penelitian tindakan kelas pada mata pelajaran Matematika tentang mengurutkan bilangan pecahan. Dalam flowchart siklus berulang yang dikemukakan oleh Kemmis dan Mc. Taggart digambarkan bahwa bila dalam pembelajaran awal pencapaian tujuan pembelajaran belum mencapai kriteria ketuntasan belajar $\geq 75 \%$, guru segera melakukan refleksi diri kemudian melakukan perencanaan dan pelaksanaan perbaikan pembelajaran siklus pertama. Jika pada siklus pertama pun belum berhasil, guru merefleksi kembali, merencanakan, dan melaksanakan perbaikan pembelajaran kedua, ketiga, keempat, dan seterusnya sampai target minimal ketuntasan belajar tercapai. Setelah itu baru pembelajaran pada materi berikutnya dapat dilakukan. Berikut flowchart yang menggambarkan proses perbaikan pembelajaran dengan siklus berulang dari Kemmis dan Mc. Taggart.

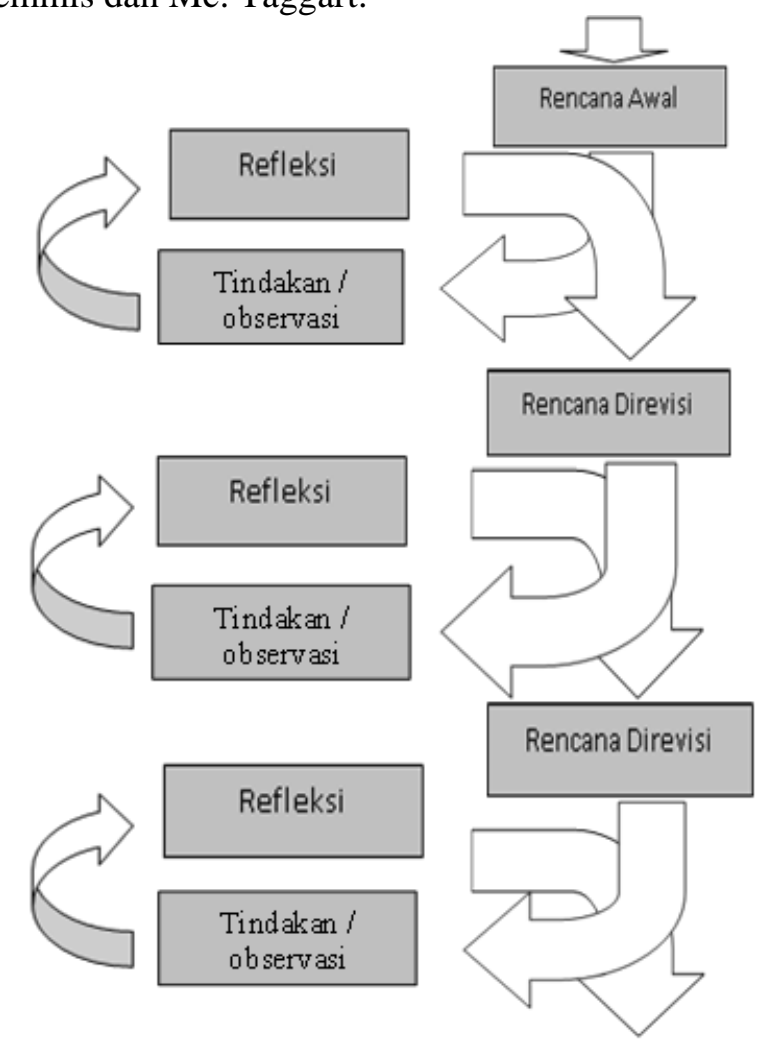

Gambar 1. Flowchart proses perbaikan pembelajaran dengan siklus berulang dari Kemmis dan Mc. Taggart

Setelah mengadakan refleksi terhadap kegiatan pembelajaran awal dan mendiskusikannya dengan teman sejawat dan supervisor, peneliti pada siklus I bermaksud memperbaiki pembelajaran tentang mengurutkan bilangan pecahan. Adapun fokus perbaikan mengenai penggunaan alat peraga berupa petak-petak urutan bilangan pecahan yang dirancang peneliti dan memperbanyak latihan soal melalui diskusi kelompok dengan harapan kompetensi (kemampuan dan keterampilan ) siswa dalam mengurutkan sekelompok bilangan pecahan yang tersusun acak dapat meningkat dan menembus batas minimal ketuntasan belajar yang telah ditetapkan. 
1. Kegiatan awal ( \pm 10 menit)

(a) Guru menyiapkan kelas, alat dan bahan pembelajaran yang diperlukan; (b) Guru memberi salam dan megadakan absensi kelas; (c) Guru mengadakan apersepsi dan menyampaikan tujuan pembelajaran.

2. Kegiatan Inti ( \pm 45 menit )

(a) Guru memperagakan cara mengurutkan sekelompok bilangan pecahan sejenis dan tak sejenis berpenyebut tidak sama menggunakan petak-petak urutan bilangan pecahan yang dirancang dan disiapkan guru disertai tanya jawab dengan siswa; (b) Guru memberi kesempatan kepada siswa untuk menanyakan hal-hal yang belum dimengerti dalam p[enjelasan di atas; (c) Guru menugasi siswa mengerjakan soal-soal latihan dalam diskusi kelompok yang terdiri atas 4-5 orang siswa; (d) Guru menugasi masing-masing kelompok untuk mempresentasikan hasil kerjanya secara bergiliran; (e) Guru bersama siswa membahas hasil kerja; (f) Guru bersama siswa menyimpulkan pelajaran.

3. Kegiatan Penutup ( \pm 15 menit )

(a) Guru memberikan mengadakan evaluasi formatif secara tertulis; (b) Guru mengadakan penilaian; (c) Guru memberikan pekerjaan rumah sebagai tindak lanjut.

Perbaikan pembelajaran mata pelajaran Matematika siklus pertama dilaksanakan oleh Peneliti pada hari Selasa, tanggal 13 Februari 2018 selama 70 menit, dimulai pukul 09.15 10.25 WIB sesuai jadwal dan rencana yang telah ditetapkan. Peneliti dibantu oleh teman sejawat Bapak Kristanto TB, S.Pd.SD. yang menjabat sebagai guru kelas V di SDN 01 Batursari. Beliau diminta oleh Peneliti untuk mengamati jalannya kegiatan perbaikan pembelajaran yang dilakukan oleh Peneliti, mencatat, serta memberikan saran dan masukan untuk mengklarifikasi sejauhmana tingkat keberhasilan perbaikan pembelajaran yang dilakukan Peneliti dan menentukan upaya tindak lanjutnya.

Data hasil pengamatan yang dilakukan oleh teman sejawat sangat diperlukan sekali untuk mengetahui kekuatan dan kelemahan tindakan penelitian serta menentukan tindakan selanjutnya. Instrumen pengamatan yang digunakan oleh teman sejawat terhadap kegiatan perbaikan pembelajaran yang dilakukan Peneliti meliputi nomor, aspek yang diamati, presentasi (ya atau tidak) dan intensitas (Baik, Cukup, atau Kurang). Pertanyaan tersebut meliputi: apakah guru menyiapkan alat, bahan, dan sumber belajar; apakah guru memberikan apersepsi yang sesuai dengan materi, apakah siswa tampak mengerti dan menanggapi apersepsi dari guru, apakah guru menyampaikan tujuan pembelajaran di awal pembelajaran, apakah guru menjelaskan materi jelas dan sistematis, apakah guru menggunakan alat peraga yang talah disiapkan, apakah siswa memahami penjelasan materi yang disampaikan guru, apakah siswa diberi kesempatan bertanya, apakah guru menggunakan metode diskusi kelompok dan latihan soal, apakah metode yang digunakan guru sesuai dan efektif untuk pencapaian tujuan pembelajaran, apakah guru membimbing siswa dalam diskusi kelompok, apakah guru memberikan penguatan yang tepat selama pembelajaran berlangsung, apakah guru mengadakan pembahasan terhadap hasil kerja siswa, apakah di akhir kegiatan guru menyimpulkan pelajaran yang melibatkan siswa, apakah guru mengadakan pemantapan di akhir pelajaran, apakah guru mengadakan evaluasi formatif di akhir pembelajaran, apakah secara keseluruhan guru mengelola kelas dengan baik, apakah guru menyelesaikan pembelajaran tepat waktu, dan apakah secara keseluruhan pembelajaran menarik ,menyenangkan dan menantang bagi siswa.

Refleksi merupakan analisis hasil pengamatan dan pengumpulan data yang dilakukan oleh teman sejawat terhadap pelaksanaan tindakan guru pada siklus I. Hasil olah data pada tahap ini untuk mengetahui tingkat keberhasilan tindakan yang telah dijalankan terkait tingkat capaian ketuntasan belajar siswa. Di samping itu hasil analisis dapat digunakan menentukan siklus berikutnya perlu dilaksanakan atau dihentikan. Begitu seterusnya sampai dua siklus 


\section{HASIL DAN PEMBAHASAN}

\section{Hasil}

Suatu kegiatan pembelajaran akan selalu diakhiri dengan pelaksanaan evaluasi untuk mengetahui sejauh mana tujuan yang telah ditetapkan dapat tercapai. Hasil evaluasi merupakan salah satu hal yang mendasari pelaksanaan tindak lanjut dari kegiatan pembelajaran yang telah dilaksanakan. Demikian pula dengan kegiatan perbaikan pembelajaran melalui penelitian tindakan kelas yang dilakukan Peneliti. Berikut ini akan dideskripsikan hasil penelitian tindakan kelas yang telah dilakukan Peneliti.

1. Pembelajaran Awal

Analisi hasil evaluasi pembelajaran awal mata peajaran matematika dengan materi pokok tentang mengurutkan bilangan pecahan. Diketahui ternyata hanya ada seorang siswa yang berhasil mencapai batas minimal ketuntasan belajar yang telah ditetapkan. Nilai tertinggi 80 dan nilai terendah 30 sebanyak tiga siswa. Rata-rata kelas sebesar 52,94 dan persentase ketuntasan belajar 5,88\%. Hasil analisis nilai awal dapat dilihat dengan jelas pada Gambar 2.

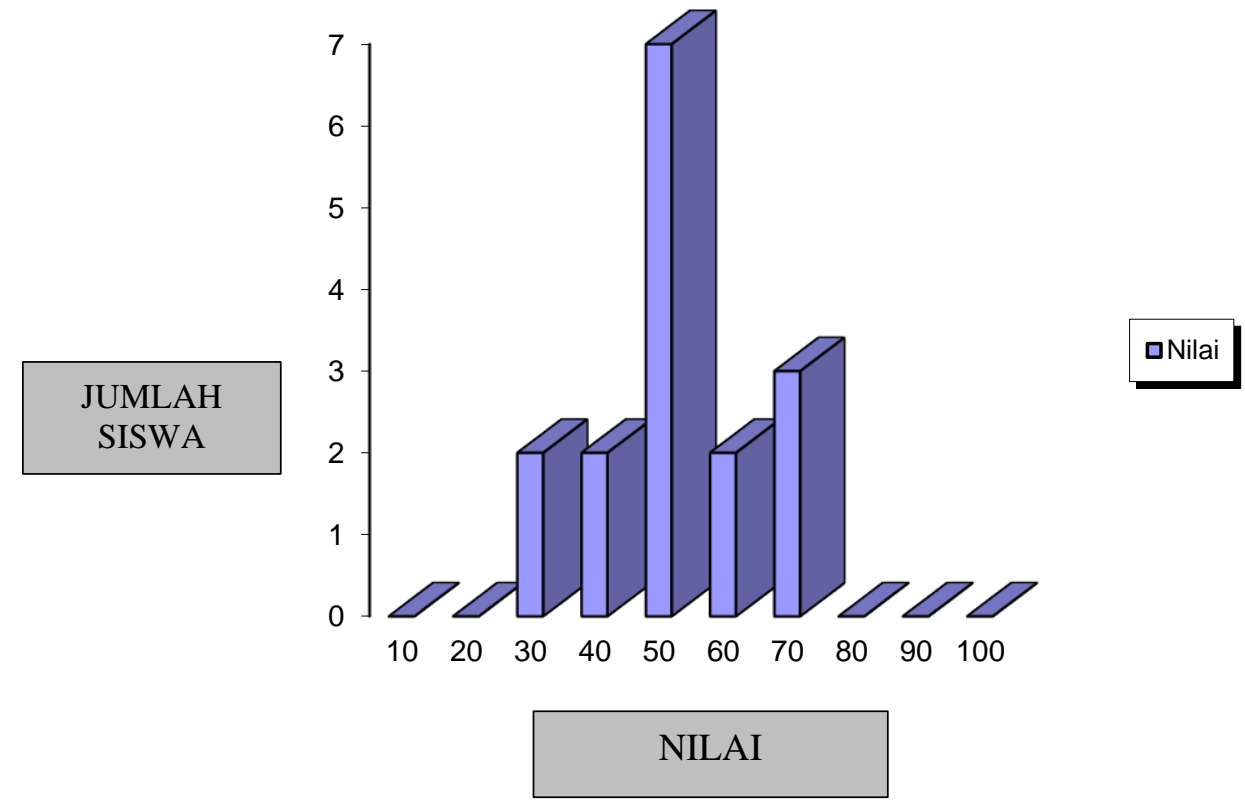

Gambar 2. Hasil Tes Formatif Pembelajaran Awal Matematika Kelas VI

\section{Pembelajaran Siklus I}

Pada perbaikan pembelajaran I, Peneliti melakukan perbaikan dengan tujuan untuk meningkatkan kemampuan dan keterampilan siswa dalam mengurutkan sekelompok bilangan pecahan berpenyebut tidak sama dengan menggunakan alat peraga petak-petak urutan bilangan pecahan dan meningkatkan latihan soal-soal. Setelah diadakan evaluasi formatif, hasilnya cukup menggembirakan dan terjadi peningkatan prestasi belajar siswa. Nilai terendah dari 30 menjadi 50 dan nilai tertinggi naik dari 80 menjadi 100. Nilai rata-rata kelas pun meningkat dari 52,94 menjadi 73,52. Jumlah siswa yang mencapai ketuntasan belajar ada 11 siswa atau $64,70 \%$. Paparan tentang hasil analisis nilai fomatif dapat dilihat pada Gambar 3. 


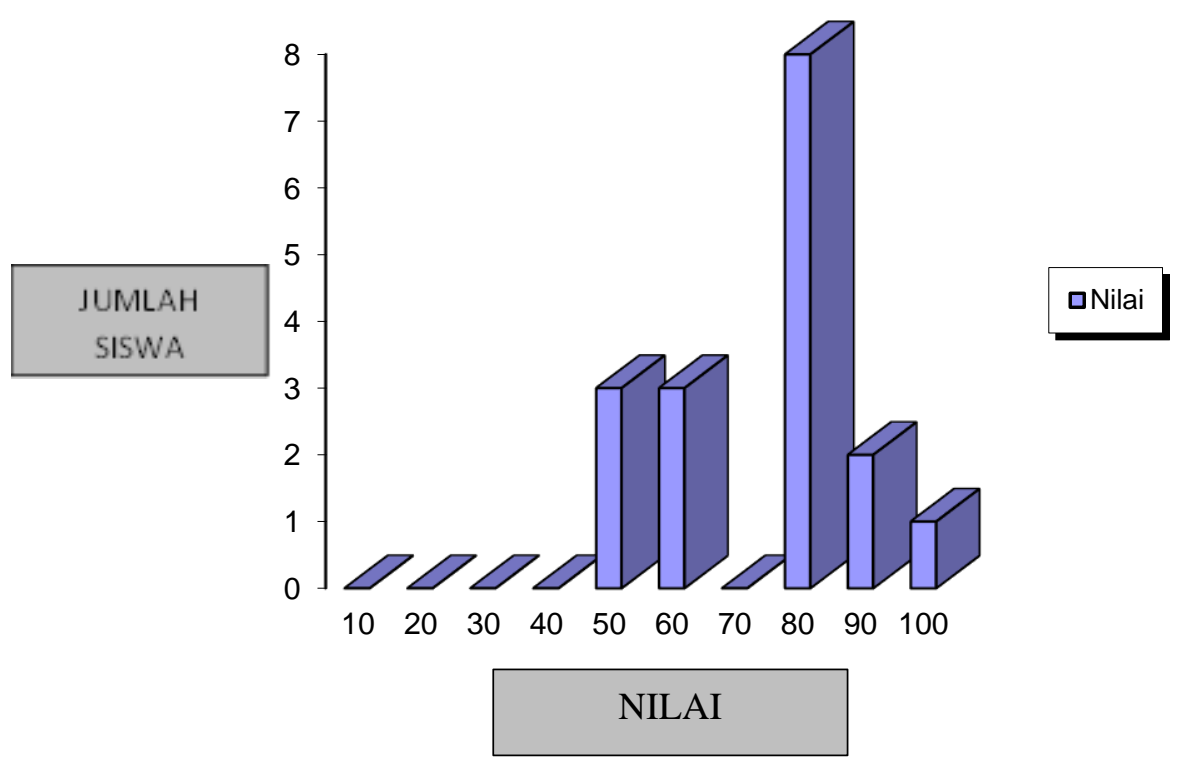

Gambar 3. Hasil Tes Formatif Pembelajaran Siklus I Matematika Kelas Vi

\section{Pembelajaran Siklus II}

Pembelajaran siklus II dilaksanakan Peneliti dengan penekanan pada peningkatan bimbingan individu terhadap siswa yang belum tuntas dalam belajar dan peningkatan penggunaan penguatan (reinforcement) dalam pembelajaran untuk lebih memotivasi belajar siswa. Setelah pembelajaran dilakukan oleh Peneliti sesuai rencana dan diakhir pembelajaran dilaksanakan evaluasi formatif, ternyata prestasi belajar siswa pun meningkat. Nilai tertinggi (100) yang semula dicapai oleh seorang siswa, sekarang dapat dicapai oleh 7 siswa, namun masih ada seorang siswa yang mendapat nilai terendah 50. Siswa yang mencapai ketuntasan belajar yang telah ditetapkan menjadi 14 siswa atau mencapai persentase sebesar 82,35\%. Di bawah ini gambar hasil analisis nilai tes formatif pembelajaran siklus II.

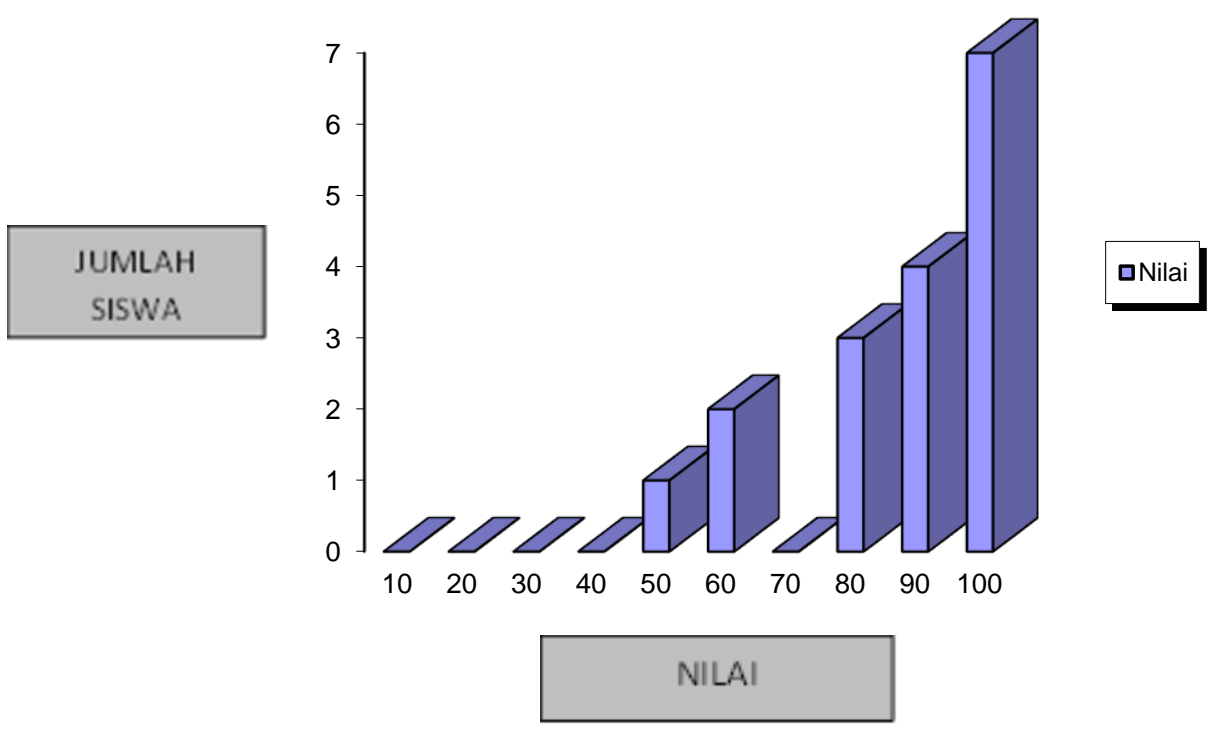

Gambar 4. Hasil Tes Formatif Pembelajaran Siklus II Matematika Kelas VI 
Agar lebih jelas paparan tentang peningkatan pencapaian ketuntasan belajar siswa dalam perbaikan pembelajaran matematika dengan materi pokok mengurutkan bilangan pecahan dari pembelajaran awal sampai pembelajaran siklus II, Peneliti akan memaparkannya dalam bentuk Tabel 1, Gambar 5, dan Gambar 6.

Tabel 1. Perkembangan pencapaian ketuntasan belajar pada pembelajaran matematika kelas VI tentang mengurutkan bilangan pecahan

\begin{tabular}{llccc}
\hline & Kategori & Pembalajaran Awal & Siklus I & Siklus II \\
\hline Tuntas & Jumlah Siswa & 1 & 11 & 14 \\
& Persentase (\%) & 5,88 & 64,70 & 82,35 \\
Belum & Jumlah Siswa & 16 & 6 & 3 \\
Tuntas & Persentase (\%) & 94,11 & 35,30 & 17,65 \\
Perubahan & Jumlah Siswa & - & 10 & 3 \\
Ketuntasan & Persentase (\%) & - & 58,82 & 17,65 \\
\hline
\end{tabular}

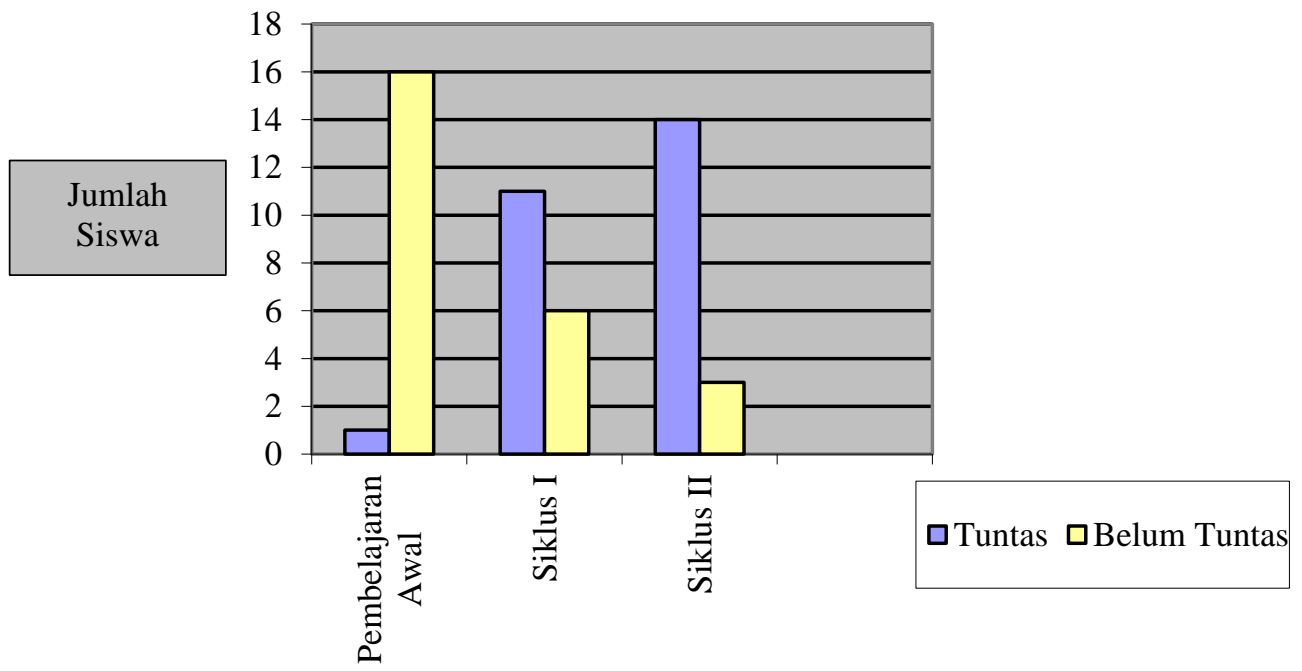

Gambar 5. Perbandingan ketuntasan belajar siswa pada pembelajaran matematika kelas VI tentang mengurutkan bilangan pecahan

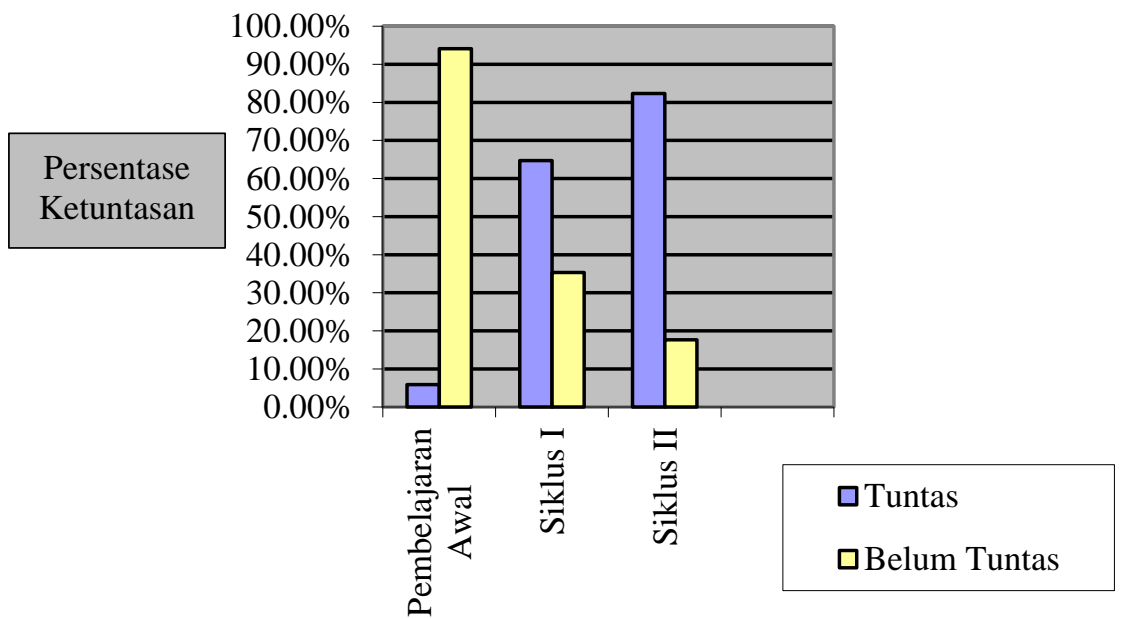

Gambar 6. Perbandingan persentase ketuntasan belajar siswa pada pembelajaran matematika kelas VI tentang mengurutkan bilangan pecahan 


\section{Pembahasan}

\section{Perbaikan Pembelajaran Siklus I}

Perolehnya hasil penilaian yang rendah dalam pembelajaran awal tentang mengurutkan bilangan pecahan oleh siswa, menandakan adanya permasalahan yang muncul dalam pembelajaran yang dilakukan oleh Peneliti di kelasnya. Dengan refleksi diri tentang pembelajaran yang telah dilakukan dan dengan bantuan teman sejawat maupun supervisor diperoleh identifikasi tentang permasalahan tersebut adalah adanya kesulitan siswa dalam menyamakan penyebut dalam sekelompok bilangan pecahan dan seringnya siswa mengalami kesalahan dalam menempatkan urutan tertentu dari sekelompok bilangan pecahan yang telah disamakan penyebutnya.

Hasil analisis yang dilakukan oleh Peneliti dengan bantuan teman sejawat dan supervisor mengarah pada interpretasi bahwa banyaknya siswa yang mengalami kesulitan dalam menyamakan penyebut dan menempatkannya dalam urutan tertentu karena Peneliti tidak menggunakan alat peraga yang tepat, penjelasan materi kurang sistematis, dan kurangnya latihan pengerjaan soal-soal oleh siswa.

Peneliti dibantu oleh teman sejawat dan supervisor kemudian membuat perencanaan dan melaksanakan perbaikan pembelajaran yang hasilnya dapat dilihat dalam Bab III laporan ini. Dalam paparan tersebut dapat diketahui bahwa penggunaan alat peraga petak-petak urutan bilangan pecahan yang dirancang Peneliti ternyata dapat meningkatkan kemampuan dan keterampilan siswa dalam mengurutkan sekelompok bilangan pecahan yang diacak urutannya. Jika pada pembelajaran awal nilai rata-rata tes formatif hanya 52,94, pada perbaikan pembelajaran siklus I yang disertai penggunaan alat peraga oleh Peneliti, nilai rata-rata tes formatif dapat meningkat menjadi 73,52. Persentase ketuntasan belajar pun meningkat dari $5,88 \%$ menjadi $64,70 \%$.

Meningkatnya kemampuan dan keterampilan siswa di atas merupakan dampak positif dari usaha Peneliti menggunakan alat peraga petak-petak urutan bilangan pecahan dalam pembelajaran yang dilakukan, serta penjelasan materi lebih sistematis dari materi yang lebih mudah ke yang lebih sulit. Peneliti mengakui benar bahwa penggunaan alat peraga dalam pembelajaran sangat diperlukan agar pembelajaran lebih baik dan mempermudah pencapaian tujuan pembelajaran yang telah ditetapkan. Hal ini sesuai dengan pendapat yang diutarakan oleh Hartono (1996) yang mengatakan bahwa prinsip pembelajaran yang baik adalah apabila proses pembelajaran tersebut mampu mengembangkan konsep, generalisasi, dari bahan abstrak, menjadi suatu hal yang jelas dan nyata. Sumber belajar yang digunakan oleh siswa maupun guru adalah buku-buku dan informasi, tetapi akan menjadi lebih jelas dan efektif jika pengajar menyertai dengan alat peraga yang dapat membantu menjelaskan bahan secara lebih realistik. Pernyataan tersebut dipertegas lagi oleh Nasution (1986) yang menyatakan bahwa penyakit yang paling berkecamuk di sekolah adalah verbalisme, yang terdapat di semua situasi belajar. Hal tersebut di atas mengisyaratkan kepada Peneliti dan para guru pada umumnya bahwa salah satu tugas penting dari seorang guru adalah menentukan alat peraga dalam perencanaan dan pelaksanaan pembelajaran di kelasnya di samping tugas-tugas pokok lainnya. Penggunaan alat peraga oleh Peneliti sebagai fokus dalam perbaikan pembelajaran didasari pula oleh berbagai pendapat dan pandangan dari pakar dan ahli pendidikan yang pada dasarnya menyatakan pentingnya alat peraga dalam pembelajaran.

Teori belajar Brunner pada tahap II menyatakan bahwa setelah memanipulasi benda secara nyata melalui persoalan keseharian dari dunia sekitarnya, dilanjutkan dengan membentuk modelnya sebagai bayangan mental dari benda atau peristiwa keseharian tersebut. Model ini berupa gambaran dari bayangan. Peneliti dalam hal ini menganggap petak-petak urutan bilangan pecahan adalah alat peraga yang merupakan model atau gambaran bayangan, mengingat siswa kelas VI SD berada pada akhir thap operasional konkret dan awal tahap operasional formal dalam kemampuan berfikir menurut Piaget. Dalam tahap ini siswa sudah dapat berfikir 
sistematis dalam menyamakan penyebut pecahan dan menempatkan letak urutan tertentu dari sekelompok bilangan pecahan dengan benar.

Brunner dan Kenney dalam teorema notasi dan teorema kontras dan variasi menyatakan bahwa dalam pengajaran suatu konsep, penggunaan notasi-notasi matematika diberikan secara bertahap, dimulai dari yang sederhana ke yang lebih kompleks notasinya. Konsep dari yang konkret ke yang lebih abstrak harus dilakukan dengan kegiatan pengkontrasan dan beranekararagaman. Peneliti menerapkan teori ini dalam menjelaskan cara menjadikan pecahan sejenis, menyamakan penyebut, dan cara mengurutkan bilangan pecahan dilakukan secara sistematis dari yang mudah ke yang sukar.

Dienes mengemukakan bahwa dalam mengajar matematika supaya menggunakan alat peraga atau model dan pengajarannya harus beraneka ragam serta sesuai dengan konsep yang akan ditanamkan. Gagne dalam tahap belajar konsep (concept learning) mengatakan siswa dapat mengenal atau melihat sifat bersama dari suatu benda atau peristiwa, dan pada tahap belajar aturan (rule learning) siswa sudah mempu memberikan respon terhadap semua stimulus dengan segala macam perbuatan. Teori ini mendasari Peneliti bahwa dalam menyamakan penyebut sekelompok bilangan pecahan yang harus diurutkan, siswa harus mengenal sifat dari angka-angka penyebut tersebut untuk menentukan kelipatan persekutuannya atau KPK, menyesuaikan pembilang dan menentukan urutan yang benar. Jadi ilmu yang lebih dulu akan menjadi dasar ilmu berikutnya. Kemp dan Dayton (1985), Udin S Winata Putra (1999) menegaskan manfaat dan pentingnya penggunaan media dan alat peraga dalam pembelajaran sebagai pemberi kontribusi yang sangat besar bagi ketercapaian tujuan pembelajaran karena media dan alat peraga dapat mewujudkan situasi belajar yang interaktif dan efektif.

\section{Perbaikan Pembelajaran Siklus II}

Perbaikan pembelajaran I dapat dikatakan cukup berhasil, tetapi belum dapat mencapai batas minimal ketuntasan belajar $\geq 75 \%$ yang ditetapkan oleh Peneliti. Berdasarkan hasil refleksi dan diskusi dengan teman sejawat dan supervisor tentang masih adanya 6 siswa $(35,30 \%)$ yang belum mencapai ketuntasan belajar diinterpetasikan bahwa Peneliti dalam pembelajaran kurang memperhatikan perbedaan individu yang ditunjukkan kurangnya intensitas Peneliti dalam memberikan bimbingan secara individu terhadap siswa yang diduga mengalami kesulitan, dan juga Peneliti kurang dalam memberikan penguatan yang sangat dibutuhkan siswa sebagai motivasi belajar, misalnya tidak disampaikannya tujuan pembelajaran di awal kegiatan.

Peneliti membuat perencanaan dan melaksanakan perbaikan pembelajaran siklus II dengan penekanan pada peningkatan pemberian bimbingan individu dan pemberian penguatan (reinforcement) dalam proses pembelajaran dengan tidak mengurangi keberhasilan yang telah dicapai pada siklus I. Dalam prinsip belajar tuntas (mastery learning) disebutkan hal-hal berikutt: (a) adanya perbedaan kemampuan dalam pelajaran sehingga kecepatan belajar dalam menyelesaikan tugas akan terdapat perbedaan waktu, (b) perbedaan waktu belajar pada setiap siswa ikut menentukan tingkat keberhasilan dalam menyelesaikan tugasnya, serta (c) dengan penyediaan waktu yang ideal dengan penggunaan metode yang tepat, maka setiap siswa akan mendapat ketuntasan dalam belajar.

Perbaikan pembelajaran siklus II merupakan upaya Peneliti untuk memberikan kesempatan kepada siswa yang belum mencapai ketuntasan belajar minimal untuk dapat mencapainya dengan pemberian pelayanan yang lebih melalui bimbingan individual dan atau tutor sebaya dari siswa yang telah mencapai ketuntasan dahulu sehingga kemampuannya akan semakin melekat dalam diri siswa dan berefek positif pada peningkatan prestasi belajar siswa. Penyampaian tujuan pembelajaran di awal kegiatan merupakan salah satu upaya memberikan stimulus guna membangkitkan motivasi belajar siswa. Dengan mengetahui tujuan yang akan dicapai, siswa akan mengetahui apa yang harus dilakukan untuk mencapai tujuan tersebut dan menyadari bahwa apa yang akan dilakukan bermakna baginya. Stimulus-stimulus atau rangsangan-rangsangan sangat perlu dimunculkan guru agar dapat mendapat respon positif dari 
siswa dalam upaya pencapaian tujuan. Penguatan (reinforcement) perlu dilakukan untuk memperkuat lekatnya hasil belajar siswa.

Melalui Diagram Batang di atas terlihat adanya kenaikan jumlah siswa yang mencapai ketuntasan belajar minimal sebanyak 11 siswa $(64,70 \%)$ menjadi 14 siswa $(82,35 \%)$. Rata-rata kelas juga meningkat dari 73,52 menjadi 86,47. Keberhasilan ini cukup membanggakan Peneliti meskipun disisi lain ketuntasan belajar belum mencapai 100\% karena masih ada 3 siswa $(17,65 \%)$ yang belum mencapai batas tuntas minimal. Permasalahan ini sebenarnya perlu dikaji kembali, tetapi mengingat target minimal ketuntasan belajar yang telah ditetapkan sebesar $\geq 75 \%$ sudah tercapai dan siklus ini dihentikan.

\section{PENUTUP}

Dari pelaksanaan perbaikan pembelajaran melalui penelitian tindakan kelas yang dilakukan oleh Peneliti pada mata pelajaran Matematika tentang mengurutkan sekelompok bilangan pecahan yang tersusun acak diperoleh kesimpulan sebagai berikut bahwa Penggunaan alat peraga berupa petak-petak urutan bilangan pecahan yang disertai penjelasan secara sistematis dalam pembelajaran oleh guru mampu meningkatkan kemampuan dan keterampilan siswa dalam mengurutkan sekelompok bilangan pecahan yang tersusun acak ke dalam urutan tertentu (dari yang terkecil atau yang terbesar). Terjadi kenaikan jumlah siswa yang mencapai ketuntasan belajar minimal sebanyak 11 siswa $(64,70 \%)$ menjadi 14 siswa $(82,35 \%)$. Nilai ratarata kelas juga meningkat dari 73,52 menjadi 86,47. Keberhasilan ini cukup membanggakan Peneliti meskipun disisi lain ketuntasan belajar belum mencapai $100 \%$ karena masih ada 3 siswa $(17,65 \%)$ yang belum mencapai batas tuntas minimal. Guru sebagai pendidik dan pembelajar harus benar-benar mempunyai kematangan didaktik dan metodik, mampu dan mau memahami siswa sebagai individu yang unik dengan segala keberagaman latar belakang dan kemampuan. Gunakanlah media dan alat peraga, serta metode yang tepat dalam setiap pelaksanaan pembelajaran kepada siswa, mengingat siswa SD mayoritas masih berada dalam tahap operasional konkret. Guru juga harus mempunyai kiat untuk terus belajar, bertanya, dan terbuka terhadap permasalahan yang dihadapi di kelasnya, serta berusaha menemukan solusinya dengan cepat dan tepat demi tercapainya tujuan pendidikan yang diharapkan.

\section{DAFTAR PUSTAKA}

Andayani. (2007). Pemantapan Kemampuan Profesional. Jakarta: Universitas Terbuka. Arief, S., Sadiman. (2003). Media Pendidikan. Jakarta: PT. Raja Grafindo Persada. Karso. (2004). Pendidikan Matematika I. Jakarta: Universitas Terbuka. Khafid, M., Suyati. (2004). Matematika SD Kelas VI. Jakarta: Erlangga. Mahmud, M. D. (1989). Psikologi Pendidikan. Jakarta: Depdikbud.

Mikarsa, H. L. (2007). Pendidikan Anak di SD. Jakarta: Universitas Terbuka Suciati. (2007). Belajar dan Pembelajaran 2. Jakarta: Universitas Terbuka. Sumantri, M. (2006). Perkembangan Peserta Didik. Jakarta: Universitas Terbuka. Supardjo. (2004). Matematika 6 Gemar Berhitung. Solo: PT. Tiga Serangkai Pustaka Mandiri. Suparno, M. Y. (2005). Keterampilan Dasar Menulis. Jakarta: Universitas Terbuka. Syamsudin, A., \& Nandang, B. (2006). Profesi keguruan 2. Jakarta: Universitas Terbuka. Wahyudi, D., Supriadi, I. A. (2005). Pengantar Pendidikan. Jakarta: Universitas Jakarta. Wardani, I.G.A.K. (2005). Penelitian Tindakan Kelas. Jakarta: Universitas Terbuka. Widyaiswara Tim. (2005). Modul Pembelajaran Diklat Guru SD/MI Mata Pelajaran PKPS. Semarang LPMP Jawa Tengah. 